\title{
ОСОБЛИВОСТІ ПЕРЕБІГУ ГОСТРИХ КИШКОВИХ ІНФЕКЦІЙ, СПРИЧИНЕНИХ УМОВНО-ПАТОГЕННИМИ МІКРООРГАНІЗМАМИ ТА ВІРУСАМИ, В СУЧАСНИХ УМОВАХ
}

\author{
Сумський державний університет
}

\begin{abstract}
Доведено, що в етіологічній структурі гострих кишкових інфекцій у сучасних умовах переважають Klebsiella pneumoniae (31,4\%), віруси (15,7\%), ентеропатогенні кишкові палички (11,4\%), Pseudomonas aeruginosae $(10,0 \%)(p<0,01)$. Досліджені інтегральні маркери інтоксикації першого рівня (температура тіла, нудота, блювання, слабкість, біль голови, уживоті будь-якої локалізації тощо) та інтегративні показники ендогенної інтоксикації дозволили констатувати їх зростання у гострому періоді недуги у всіх хворих ( $p<0,05-0,001)$. Відбувається збільшення лейкоцитарного індексу інтоксикації (у 4,3-5,5 разу), гематологічного показника інтоксикації (у 5,0-7,4), індексу зсуву лейкоцитів (у 2,1-2,6) та значне зменшення лімфоцитарного індексу (у 2,0-2,2 разу) $(p<0,05)$. При дослідженні мікробіоченозу кишечнику в гострому періоді виявлено зменшення кількості біфрідобактерій, лактобацил, кишкової палички з повноцінними фрерментативними властивостями і зростання інших представників умовно патогенних мікроорганізмів, гемолізуючої кишкової палички та грибів роду Candida ( $p<0,05-0,001)$.
\end{abstract}

Ключові слова: гострі кишкові інфрекції, клініка, епідеміологія, інтегративні показники ендогенної інтоксикації, мікробіоценоз кишечнику.

Протягом усього часу існування людства гострі кишкові інсрекції (ГКІ) залишаються актуальною патологією, яка потребує постійного удосконалення діагностики, лікування і просілактики. Бактерійні та вірусні діареї, за даними ВООЗ, $є$ найбільш поширеними у світі інфекційними хворобами [1-3].

Етіологічна структура інфрекційних захворювань останнім часом суттєво змінилась, що пов'язано із постійною еволюцією бактерій і залученням у патологічний процес умовно патогенних мікроорганізмів (УПМ), які присутні в складі нормальної мікрофрлори кишечнику людини, але при різних ендогенних і екзогенних взаємодіях реєструються як етіопатогени $[3,4]$.
ГКІ, що спричиняються УПМ, виникають при певних умовах зараження (масивність інфрікуючої дози, зниження реактивності організму) і характеризуються однотипністю кишкових проявів [1].

Захворюваність на ГKІ, що викликані УПМ родини Enterobacteriaceae, щорічно зростає у всіх вікових групах. Але, оскільки тривалість симптомів у більшості випадків складає близько 1-3 діб, населення переважно вдається до самолікування, внаслідок чого офіційні статистичні дані не відображають реальні показники в повному обсязі [3].

Існує багато протиріч стосовно етіологічної значущості УПМ при ГКІ, оскільки не завжди фракт виділення збудника свідчить про його роль у виникненні захворювання, а наростання титру антитіл при проведенні реакції аглютинації (РА) залежить від імунної реактивності організму хворого, яка часто $є$ недостатньою [5]. До того ж не усі бактерії дають ріст на поживних середовищах, а при проведенні серологічних досліджень можливі хибнопозитивні результати через антигенну подібність різних видів УПМ $[4,5]$.

До останнього часу достеменно не з'ясовані сучасні епідеміологічні та клінічні дані, за якими можна було б здійснювати ймовірне діагностування ГКІ, наближене до етіологічного чинника, що спричинив недугу.

Мета роботи - встановити клініко-епідеміологічні та лабораторні особливості перебігу ГКІ, спричинених бактерійними і вірусними чинниками, на сучасному етапі.

\section{Пацієнти і методи}

Проведено клініко-лабораторне обстеження 70 хворих на ГКІ, викликані УПМ і вірусами, які перебували на лікуванні у Сумській обласній клінічній інсрекційній лікарні ім. 3.Й. Красовицького. Госпіталізація хворих на ГКІ відбувалася на $(2,11 \pm 0,18)$ добу. Усі лікувально-діагностичні процедури здійснювали за інсрормованою згодою пацієнтів.

Критеріями залучення у дослідження були: клінікоанамнестичні дані (госпіталізація не пізніше 72 год від по- 
чатку захворювання; наявність типових клінічних проявів ГКІ середньотяжкого перебігу (гострий початок, інтоксикаційний, больовий, діарейний синдроми, ознаки зневоднення); дані епідеміологічного анамнезу (вживання недоброякісних або сумнівних за якістю продуктів, спалахи тощо); лабораторні (при проведенні бактеріологічного дослідження виділення з промивних вод шлунка i/або блювоти, i/або випорожнень культур УПМ у кількості не менше ніж $10^{5}$ КУО/г; наявність антигенів у фекаліях при проведенні дослідження швидкими тестами (Rota-Adeno, Norovirus - «R-biopharm» (Darmstadt, Germany) перед початком лікування; наростання титру антитіл у парних сироватках крові при проведенні РА з автокультурою; наявність антитіл у дослідженні методом імуноферментного аналізу (ІФА) (Norovirus, Rotavirus - «R-biopharm» (Darmstadt, Germany).

Критеріями вилучення 3 дослідження були: клінікоанамнестичні дані (госпіталізація пізніше 72 год від початку захворювання; легкий або тяжкий перебіг ГКІ; наявність супровідної патології шлунково-кишкового тракту та гепатобіліарної системи; хронічні захворювання серцево-судинної, сечовидільної, ендокринної системи у стадії декомпенсації); лабораторні (негативні результати бактеріологічного/вірусологічного і серологічних досліджень; позитивні результати швидких тестів (Cryptosporidium/Giardia Combi), досліджень методом IФА (Clostridium difficile GDH, Clostridium difficile toxin A/B, Giardia - «R-biopharm» (Darmstadt, Germany).

Обстеження хворих включало: збір анамнестичних даних; клініко-лабораторні дослідження - клінічний аналіз крові (аналізатор Cobas Micros), бактеріологічне/ вірусологічне дослідження калу, серологічне та ІФА дослідження крові 3 метою з'ясування етіології ГKІ; розраховували інтегративні показники ендогенної інтоксикації - лейкоцитарний індекс інтоксикації (ЛІІ), гематологічний показник інтоксикації (ГПІ), індекс зсуву лейкоцитів (ІЗЛК), лімфоцитарний індекс (Ілімф) [6-8].

Крім загальноклінічних обстежень у всіх пацієнтів був досліджений мікробіоценоз товстої кишки до початку лікування. Бактеріологічні дослідження проводили за загальноприйнятими методиками. У здорових осіб і пацієнтів досліджуваних груп вивчали кількісний і якісний склад мікрофрлори кишечнику з визначенням кількості представників мікробіоти y lg КУО/г. Для оцінки мікробіоценозу кишечнику використовували загальноприйняті мікробіологічні критерії $[3,9]$.

При ушпиталенні усім пацієнтам призначали базисну терапію: промивання шлунка і/або кишечнику, дієту № 4 за Певзнером, оральну (регідрон) і/або парентеральну регідратацію (трисіль, розчин Рингера, 5 \% розчин глюкози, 0,9 \% розчин натрію хлориду); фрерменти (панкреатин, мезим), ентеросорбенти (атоксил, ентеросгель, смекта).

Залежно від збудника всі обстежені були розподілені на три групи.
Групу порівняння склали 20 клініко-анамнестично здорових донорів крові з Сумського обласного центру служби крові і трансорузіології віком $(37,95 \pm 1,72)$ року. Статевий склад даної групи був рівноцінним - по 10 осіб чоловіків і жінок.

Усі дані заносили в «Електронну карту дослідження». Результати клінічного спостереження та проведених досліджень були опрацьовані методом варіаційної статистики 3 використанням комп'ютерних програм Microsoft Office Excel 2010, Statistica 10 і онлайн калькулятора (http://medstatistic. ru/calculators/calchit.html).

\section{Результати досліджень та їх обговорення}

Серед обстежених було 32 чоловіки, 38 жінок. Середній вік хворих склав $(36,20 \pm 1,92)$ року. У пацієнтів 3 вірусною етіологією недуги спостерігалась тенденція до переважання осіб більш старшого віку - $(49,82 \pm 6,81)$ року.

Бактеріологічне/вірусологічне підтвердження діагнозу було здійснено всім пацієнтам. Етіологічними чинниками серед УПМ найчастіше була K. pneumoniae (22 особи; 31,4 \%), ці хворі склали групу ГКІ II KІ. Віруси спричинили захворювання в 11 (15,7\%) осіб - група ГКI III Vir (частка норовірусів складала 11,4 \%; ротавірусів - 4,3 \%). Вірусна етіологія недуги у чоловіків виявлялася вдвічі рідше $(\mathrm{p}<0,05)$. У групу ГКІ І увійшли усі інші хворі (37 осіб; 52,8 \%), в яких найчастіше виділяли ентеропатогенні кишкові палички (ЕПКП) (8 хворих), Pseudomonas aeruginosae (7), Enterobacter cloacea (6), Citrobacter freundii (3). Гриби роду Candida як окремий етіологічний чинник визначено в 1 хворого. Звертають на себе увагу комбінації Enterobacter cloacea/Morganella morganii - 1 та Pseudomonas aeruginosae/Candida - 2 випадки. Ймовірно, дані УПм мають тісні мікробіоценотичні зв'язки, можуть бути симбіонтами в складі мікрофрлори товстої кишки. На нашу думку, вищезазначене опосередковано вказує на високий адгезивний і колонізаційний потенціал етіологічних чинників. У сучасних умовах превалює $К$. pneumoniae серед чинників ГКІ ( $<<0.05)$, що збігається з результатами інших дослідників [3-5, 10].

Госпіталізація хворих з кишковими інфекціями, спричиненими УПМ, відбувалася протягом року, але пік припадав на літні місяці (червень - серпень), що підтверджувало дані про стимулюючий вплив температури довкілля на розмноження УПМ і продукування ними токсичних речовин $[4,5]$. Для ГКІ вірусної етіології можна чітко виділити два підвищення рівня госпіталізації: лютий - березень і липень - серпень (мал. 1). Пацієнти з ГКІ бактерійної етіології надходили до стаціонару на першу - другу добу захворювання, особи з групи ГКІ III Vir - на $(2,36 \pm 0,31)$ добу $[2,10]$. 


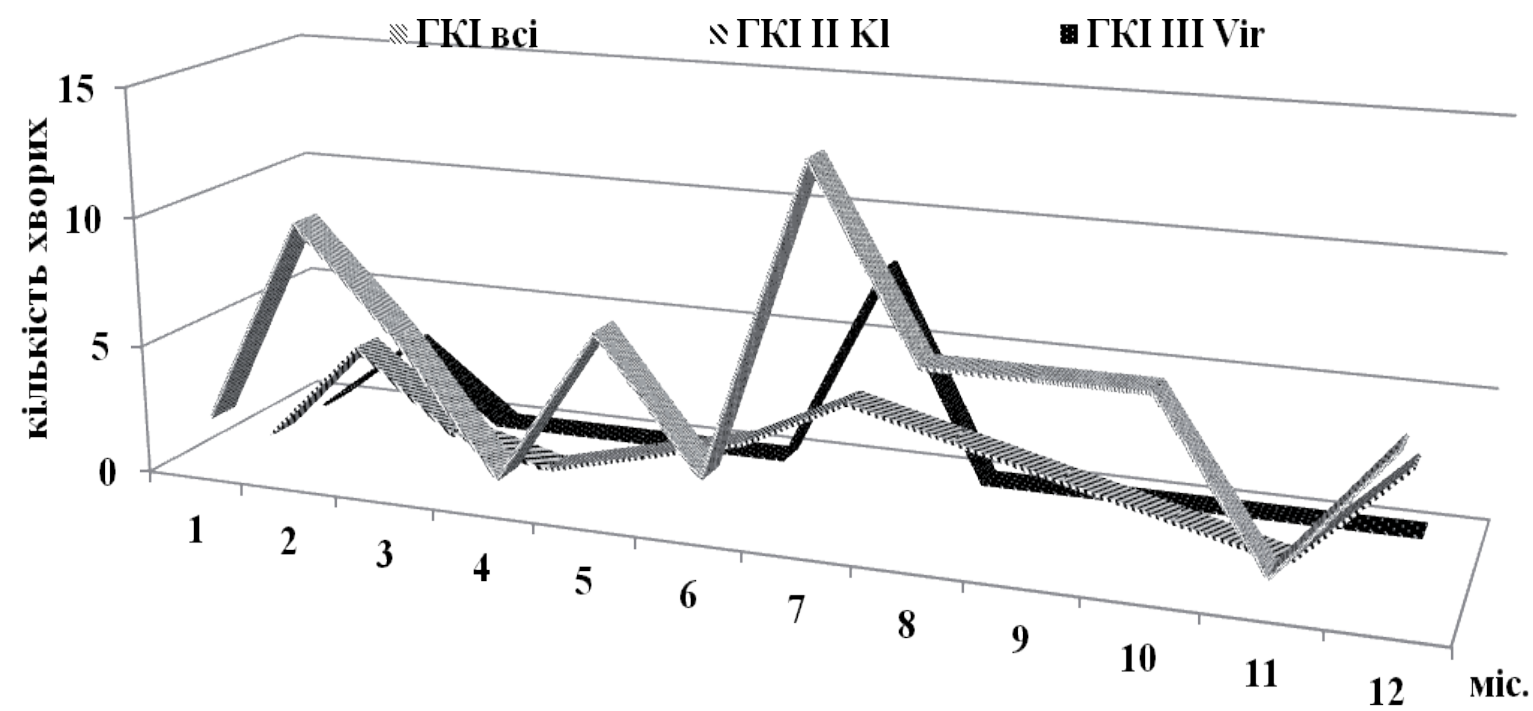

Мал. 1. Помісячна госпіталізація хворих на ГКІ, спричинені УПМ і вірусами.

При з'ясуванні епідеміологічного анамнезу було встановлено, що домінував харчовий шлях передачі ГKI $(p<0,001)$ [5]. Серед ймовірних фракторів передачі хворі на ГКІ найчастіше вказували на молочні продукти (22,6 \%), овочі й фррукти (21,0 \%), м'ясо (15,1 \%). Ковбаси та кондитерські вироби були дещо рідше (по 11,8 \%), майонез вважали причиною недуги 10,1 \% обстежених. У поодиноких випадках захворювання пов'язували 3 вживанням риби - 7,6 \% хворих. Отримані результати $€$ закономірними для сучасних складних соціальноекономічних умов проживання та не суперечать даним інших досліджень [2, 11].

Серед клінічних фрорм недуги в усіх групах переважала гастроентеритна, рідше була ентероколітна (в 1,7-2,6 разу), гастроентероколітна (у 2,5-4,3), ентеритна (у 7,810,1). У поодиноких випадках діагностували гастритну форму. Окремо слід виділити ГКІ вірусної етіології, у цій групі, окрім гастроентериту, у кожного п'ятого пацієнта було діагностовано ентеритну форму за відсутності інших (табл. 1).

У всіх пацієнтів, які увійшли до досліджуваних груп, перебіг був зазвичай типовим і відповідав картині захворювання, описаній у літературі останніх років $[4,5]$. У клінічній картині захворювання можна виділити скарги, які реєструвалися практично у всіх пацієнтів різних груп: слабкість, діарею та підвищення температури тіла. На нудоту та блювання скаржились понад 2/3 обстежених. При цьому слід зазначити, що нудоту найчастіше відмічали хворі з вірусною етіологією захворювання. Анамнестично біль голови відмічала незначна кількість пацієнтів, а в осіб з групи ГKI III Vir цей симптом відсутній (табл. 1).
Скарги на біль у різних ділянках живота відмічали всі хворі. При цьому половина обстежених вказувала на його локалізацію в мезогастрії, незначно менше - в епігастрії, рідше - у гіпогастрії. На біль у правій і лівій здухвинних ділянках скаржились лише хворі з групи ГКІ II KI.

Під час об'єктивного обстеження пацієнтів найпоширенішим симптомом був біль у животі при пальпації (у пацієнтів з групи ГКІ I - у 86,5 \%; ГКІ II KI. - у 95,5 \%; ГKI III Vir - у 100 \%), що вказує на запальний процес і співпадає з даними літератури. Переважно він локалізувався в декількох ділянках одночасно, але найчастіше в мезогастрії та в епігастрії. Слід окремо виділити групу ГKI III Vir, у пацієнтів якої біль у гіпогастрії, мезогастрії та правій здухвинній ділянці 3 однаковою частотою відмічався у 2/3 осіб і поєднувався з болем в епігастрії у всіх обстежених. У цій групі значно частіше, порівняно з іншими, була болюча ліва здухвинна ділянка.

Бурчання кишечнику при пальпації спостерігалося у третини обстежених за винятком групи ГKI III Vir, де цей симптом виявлявся в 1,4-2 рази рідше. Спазмовану сигмоподібну кишку частіше пальпували у хворих з групи ГКI III Vir. В осіб групи ГКІ II KІ. цей симптом діагностували у 2 рази рідше, а в групі ГКІ І ураження цього відділу товстої кишки не було.

У кожного третього-четвертого пацієнта була збільшена печінка до 2 см, за винятком пацієнтів групи ГКІ III Vir, в яких іiї збільшення було виразнішим, але у меншої кількості осіб. Ознаки зневоднення І ступеня виявляли з однаковою частотою незалежно від етіологічного чинника $[3,10,11]$. 
Виразність клінічних симптомів при ГКІ на догоспітальному етапі та під час госпіталізації

\begin{tabular}{|c|c|c|c|c|}
\hline \multirow{2}{*}{ Показник } & \multicolumn{4}{|c|}{ Група } \\
\hline & ГКІ всі $(\mathrm{n}=70)$ & ГKI I (n=37) & 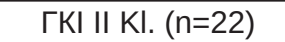 & ГKI III Vir $(\mathrm{n}=11)$ \\
\hline \multirow{5}{*}{$\begin{array}{l}\text { Клінічна фрорма, \%: } \\
\text { гастритна } \\
\text { гастроентеритна } \\
\text { гастроентероколітна } \\
\text { ентеритна } \\
\text { ентероколітна }\end{array}$} & 2,9 & 2,7 & 4,5 & $0^{6, \mathrm{~B}}$ \\
\hline & $55,7^{a}$ & $54,1^{a}$ & $45,5^{a}$ & $81,8^{a, 6, в}$ \\
\hline & 12,9 & 13,5 & 18,2 & $0^{6, \mathrm{~B}}$ \\
\hline & 7,1 & 5,4 & 4,5 & $18,2^{\text {б, в }}$ \\
\hline & 21,4 & 24,3 & 27,3 & $0^{6, \mathrm{~B}}$ \\
\hline \multirow{5}{*}{$\begin{array}{l}\text { Скарги, \%: } \\
\text { слабкість } \\
\text { гарячка } \\
\text { біль голови } \\
\text { нудота } \\
\text { блювання } \\
\text { діарея }\end{array}$} & $\begin{array}{c}98,6 \text { a } \\
90,0\end{array}$ & $\begin{array}{l}97,3 \\
86,5\end{array}$ & $\begin{array}{c}100,0 \\
90,9\end{array}$ & $\begin{array}{l}100,0 \\
100,0\end{array}$ \\
\hline & $7,1^{\mathrm{a}}$ & 10,8 & 4,5 & $0^{6,8}$ \\
\hline & 70,0 & 70,3 & 63,6 & $81,8^{\text {б, в }}$ \\
\hline & 60,0 & 54,1 & 68,2 & 63,6 \\
\hline & $95,7^{a}$ & 91,9 & 100,0 & 100,0 \\
\hline \multirow{3}{*}{$\begin{array}{l}\text { Температура, }{ }^{\circ} \mathrm{C}(\%): \text { до госпіта- } \\
\text { лізації } \\
\text { при госпіталізації } \\
\text { Зневоднення, \% }\end{array}$} & $38,04 \pm 0,10^{a}(90,0)$ & $37,89 \pm 0,12^{a}(86,5)$ & $38,13 \pm 0,20^{a}(90,9)$ & $38,53 \pm 0,27^{a}(100,0)$ \\
\hline & $37,48 \pm 0,09(77,1)$ & $37,57 \pm 0,10(81,1)$ & $37,46 \pm 0,17(77,3)$ & $37,25 \pm 0,18(63,6)$ \\
\hline & 75,7 & 75,7 & 77,3 & 72,7 \\
\hline Збільшення печінки, см (\%) & $1,88 \pm 0,23(27,1)$ & $1,59 \pm 0,16(29,7)$ & $1,67 \pm 0,40(27,3)$ & 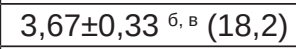 \\
\hline \multirow{3}{*}{$\begin{array}{l}\text { Локалізація болю (скарги/ } \\
\text { об’єктивно, \%): } \\
\text { епігастрій, } \\
\text { мезогастрій, } \\
\text { гіпогастрій - }\end{array}$} & $40,0 / 51,4$ & $37,8 / 54,1$ & $45,5 / 36,4^{6, \text { в }}$ & $36,4 / 100,0^{6,8}$ \\
\hline & $50,0 / 60,0$ & $45,9 / 56,8$ & $54,5 / 59,1$ & $54,5 / 72,7^{\text {в }}$ \\
\hline & $\begin{array}{c}4,3 / 47,1 \\
2,9 \text { a/ } 21,4^{\text {a }} \\
\end{array}$ & $\begin{array}{l}0^{\sigma} / 37,8^{\text {в }} \\
0^{\sigma} / 16,2^{\text {в }}\end{array}$ & $\begin{array}{c}13,6^{\text {б, в } / 54,5} \\
9,1^{\text {в }} / 31,8 \\
\end{array}$ & $\begin{array}{l}0^{\sigma} / 72,7^{\sigma, \mathrm{B}} \\
0^{\sigma} / 63,6^{6, \mathrm{~B}}\end{array}$ \\
\hline Спазм сигмоподібної кишки, \% & 2,9 & $0^{\mathrm{B}}$ & 9,1 & 18,2 \\
\hline $\begin{array}{l}\text { Бурчання кишечнику при паль- } \\
\text { пації, \% }\end{array}$ & 25,7 & 27,0 & $36,4^{\text {в }}$ & 18,2 \\
\hline
\end{tabular}

Примітки: достовірна різниця показників (р<0,05-0,001; використано t-критерій Ст'юдента та аналіз довільних таблиць спряженості з використанням критерію $\chi^{2}$ ): ${ }^{a}$ - всередині групи; ${ }^{6}-$ порівняно з групою ГKI всі; ${ }^{\text {в }}$ - між групами ГKI I, II і III.

Підвищення температури на догоспітальному етапі констатувало біля 90 \% хворих, які вимірювали її, інші або не помічали гарячки, або не здійснювали термометрію. При цьому у частини пацієнтів (від 5,4 до 36,4 \%) гарячка була короткотривалою і під час госпіталізації не перевищувала норми. В інших відбувалось її зниження.
Дослідження інтегральних маркерів інтоксикації першого рівня (гарячка, біль голови, зневоднення, біль будь-якої локалізації тощо) дозволило нам констатувати, що в гострому періоді у всіх хворих наявне зростання ендогенної інтоксикації, рівень якої не залежав від збудника $[4,6,8]$.

Таблиця 2

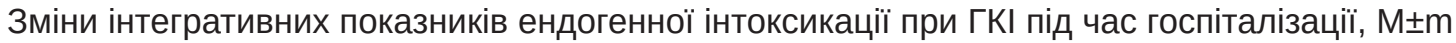

\begin{tabular}{|c|c|c|c|c|c|}
\hline \multirow{2}{*}{ Показник } & \multicolumn{5}{|c|}{ Група } \\
\hline & Норма & $\Gamma \mathrm{KI}$ всі $(\mathrm{n}=70)$ & ГКІ I (n=37) & ГКІ II KІ. $(\mathrm{n}=22)$ & ГКІ III Vir $(n=11)$ \\
\hline ЛII & $0,79 \pm 0,10$ & $4,06 \pm 0,39^{a}$ & $4,30 \pm 0,66^{\alpha}$ & $3,41 \pm 0,52^{a}$ & $4,35 \pm 0,56^{a}$ \\
\hline ГП। & $0,79 \pm 0,10$ & $5,10 \pm 0,56$ & $5,55 \pm 0,98^{a}$ & $3,95 \pm 0,59^{a}$ & $5,85 \pm 0,52^{a}$ \\
\hline ІЗЛК & $1,83 \pm 0,10$ & $4,35 \pm 0,31^{\circ}$ & $4,70 \pm 0,51^{a}$ & $4,00 \pm 0,41^{a}$ & $3,87 \pm 0,54^{a}$ \\
\hline Ілімфр & $0,510 \pm 0,030$ & $0,243 \pm 0,018^{a}$ & $0,240 \pm 0,030^{a}$ & $0,250 \pm 0,030^{a}$ & $0,230 \pm 0,020^{a}$ \\
\hline
\end{tabular}

Примітка. $^{a}$ - достовірна різниця показників щодо контрольної групи ( $<<0,05-0,001 ;$ використано t-критерій Ст'юдента) 


\section{ОРИГІНАЛЬНІ ДОСЛІДЖЕННЯ}

Рівень лейкоцитів у хворих на ГКІ був у межах норми. Так, у групі ГKІ всі вміст лейкоцитів у крові склав $(8,13 \pm 0,36) \times 10^{\%} / л$. У групі ГKI III Vir кількість лейкоцитів була значно знижена порівняно з іншими групами обстежених $(p<0,05)$.

На виражений інтоксикаційний синдром вказують інтегративні показники ендогенної інтоксикації, які були значно підвищені, порівняно 3 нормою, у всіх групах: ЛІІ - у 4,3-5,5; ГПІ - у 5,0-7,4; ІЗЛК - у 2,1-2,6 разу. Ілімф, навпаки, був зменшений у всіх групах у 2,0-2,2 разу (табл. 2). Залежності змін інтегративних показників ендогенної інтоксикації від етіології не спостерігалося $(p>0,05)[6,7]$.

При дослідженні мікробіоценозу кишечнику хворих на ГKІ було встановлено, що у гострому періоді в усіх групах хворих кількість біфрідобактерій, лактобацил і кишкової палички була на 2-3 порядки меншою, ніж у донорів, при збільшеному на 2-4 порядки рівні інших представників УПМ, гемолізуючої кишкової палички та грибів роду Candida ( $<<0,05-0,001)$. У пацієнтів з групи ГKI III Vir показник виділення грибів роду Candida був найнижчим (p<0,05-0,001), а в групі ГКІ II KІ. була відсутня гемолізуюча кишкова паличка ( $<<0,05-0,001)$ (табл. 3). Виявлені у всіх групах обстежених значні зміни мікробіоценозу кишечнику в гострому періоді обумовлені рядом фракторів як наслідок взаємодії макро- і мікроорганізмів. Формування якісного і кількісного складу мікрофрлори регулюється складними антагоністичними і синергічними відносинами між окремими представниками у складі ії біоценозів, а також контролюється фрізіологічними фракторами макроорганізму. До основних механізмів, що лімітують бактерійний ріст, відносять коливання рівня кислотності у шлунку і нижчих відділах травного тракту, стан кишкової моторики, регенераторну здатність епітелію й інші фрактори, які, безумовно, виходять із стабільного стану при ГКІ $[4,11]$.

Таблиця 3

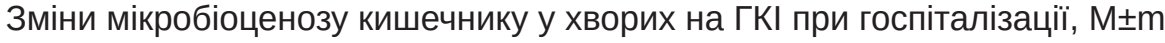

\begin{tabular}{|c|c|c|c|c|c|c|}
\hline \multirow[b]{2}{*}{ Група } & \multicolumn{6}{|c|}{ Мікроорганізми, lg КУО/г (виявлено у \% хворих) } \\
\hline & Бісрідобактерії & Лактобацили & $\begin{array}{c}\text { Загальна кіль- } \\
\text { кість E. coli }\end{array}$ & $\begin{array}{c}\text { Гемолізуюча } \\
\text { E. coli }\end{array}$ & Інші УПМ & $\begin{array}{l}\text { Гриби роду } \\
\text { Candida }\end{array}$ \\
\hline $\begin{array}{l}\text { Контрольна, Ig КУО/г } \\
(n=20) \%\end{array}$ & $\begin{array}{c}7,90 \pm 0,07 \\
100,0\end{array}$ & $\begin{array}{l}7,75 \pm 0,10 \\
100,0\end{array}$ & $\begin{array}{c}7,51 \pm 0,12 \\
100,0\end{array}$ & $0,00 \pm 0,00$ & $\begin{array}{c}0,51 \pm 0,35 \\
20,0\end{array}$ & $\begin{array}{c}0,35 \pm 0,24 \\
10,0\end{array}$ \\
\hline ГКІ всі, lg КУО/г (n=70) \% & $\begin{array}{c}5,44 \pm 0,25 \\
100,0\end{array}$ & $\begin{array}{c}5,73 \pm 0,23 \\
100,0\end{array}$ & $\begin{array}{c}5,80 \pm 0,07 \\
100,0\end{array}$ & $\begin{array}{c}3,40 \pm 1,08 \\
7,1\end{array}$ & $\begin{array}{c}3,77 \pm 0,29 \\
42,9\end{array}$ & $\begin{array}{c}3,46 \pm 0,46 \\
18,6\end{array}$ \\
\hline ГКІ I, lg КУО/Г (n=37) \% & $\begin{array}{c}5,72 \pm 0,32 \\
100,0\end{array}$ & $\begin{array}{c}6,06 \pm 0,26 \\
100,0\end{array}$ & $\begin{array}{c}5,81 \pm 0,07 \\
100,0\end{array}$ & $\begin{array}{l}1,50 \pm 0,50 \\
5,4\end{array}$ & $\begin{array}{c}3,69 \pm 0,42 \\
43,2\end{array}$ & $\begin{array}{c}3,67 \pm 0,92 \\
16,2\end{array}$ \\
\hline ГKI II KI., lg KУO/г (n=22) \% & $\begin{array}{c}4,85 \pm 0,54 \\
100,0\end{array}$ & $\begin{array}{l}5,00 \pm 0,54 \\
100,0\end{array}$ & $\begin{array}{l}5,69 \pm 0,24 \\
100,0\end{array}$ & $0,00 \pm 0,00$ & $\begin{array}{l}3,89 \pm 0,51 \\
\quad 40,9\end{array}$ & $\begin{array}{l}4,0 \pm 0,41 \\
18,2\end{array}$ \\
\hline ГКI III Vir, lg КУО/г (n=11) \% & $\begin{array}{l}5,20 \pm 0,55 \\
100,0\end{array}$ & $\begin{array}{c}5,50 \pm 0,64 \\
100,0\end{array}$ & $\begin{array}{l}5,90 \pm 0,10 \\
100,0\end{array}$ & $\begin{array}{c}4,67 \pm 1,33 \\
27,3\end{array}$ & $\begin{array}{c}3,80 \pm 0,73 \\
45,5\end{array}$ & $\begin{array}{l}2,33 \pm 0,33 \\
27,3\end{array}$ \\
\hline
\end{tabular}

Примітка. Достовірна різниця показників (р<0,05-0,001; використано t-критерій Ст'юдента та аналіз довільних таблиць спряженості з використанням критерію $\mathrm{X}^{2}$ ): ${ }^{a}$ - щодо контрольної групи; ${ }^{6}-$ всередині групи ГКІ.

\section{Висновки}

1. В етіологічній структурі ГKІ переважають K. pneumoniae (31,4\%), віруси (15,7\%), ЕПКП (11,4\%), $P$. aeruginosae $(10,0 \%)$.

2. У гострому періоді недуги зростає ендогенна інтоксикація у всіх хворих ( $(2<0,05-0,001)$, що підтверджується наявністю інтегральних маркерів інтоксикації першого рівня (100\% осіб) та збільшенням інтегративних показників ендогенної інтоксикації (ЛІІ - у 4,3-5,5; ГПІ - у 5,0-7,4; І3ЛК - у 2,1-2,6 разу) та зменшенням Ілімфр - у $2,0-2,2$ разу $(p<0,05)$.
3. Для ГKІ, спричинених К. pneumoniae, характерні локалізація болю в епігастрії, мезогастрії та здухвинних ділянках, спазм сигмоподібної кишки.

4. Для ГКІ вірусної етіології характерні спазм сигми, локалізація болю в епігастрії і лівій здухвинній ділянці, значне збільшення розмірів печінки, низький вміст у крові лейкоцитів.

5. При дослідженні мікробіоценозу кишечнику в гострому періоді встановлено зменшення кількості біфідобактерій, лактобацил, кишкової палички з повноцінними фрерментативними властивостями при збільшенні рівнів 
інших представників УПМ, гемолізуючої кишкової палички та грибів роду Candida ( $<<0,05-0,001)$.

\section{Література}

1. Бондаренко В.М. Роль диссрункции кишечного барьера в поддержании хронического воспалительного процесса различной локализации / В.М. Бондаренко, Е.В. Рябиченко // Журн. микробиол. - 2010. - № 1. - С. 92-100.

2. Павленко О.В. Особливості клініки гострих кишкових інфрекцій вірусної етіології у дорослих / О.В. Павленко, Є.В. Нікітін, Л.І. Скрипник // Інфеекційні хвороби. - 2008. - № 1. - С. 63-68.

3. Полов'ян К.С. Гострі кишкові інфекції, викликані умовнопатогенною мікрофлорою: перспективи досліджень / К.С. Полов'ян, М.Д. Чемич // Сучасні інсрекції. - 2010. - № 2. - С. 91-100.

4. Возможности адаптации условно-патогенных энтеробактерий к различным температурам / [Ю.А. Маркова, Л.А. Беловежец, И.Ю. Баров и др.] // Журн. микробиол. - 2009. - № 2. - С. 15-18.

5. Малый В.П. Общая характеристика острых кишечных инфекций / В.П. Малый // Клінічна імунологія. Алергологія. Інфектологія. - 2010. - №7 (36). - С. 14-32.

6. Андрейчин С.М. Сучасні уявлення про метаболічну ендогенну інтоксикацію / С.М. Андрейчин, Т.О. Голомша // Інфекційні хвороби. - 2012. - № 1 (67). - С. 84-88.

7. Маржохова М.Ю. Некоторые показатели синдрома интоксикации при острых кишечных инфекциях / М.Ю. Маржохова, М.А. Башиева, Ж.М. Желихажева // Эпидемиология и инфекционные болезни. - 2008. - № 6. - С. 39-42.

8. Чемич М.Д. Інтегративні показники ендогенної інтоксикації організму та гематологічні зміни при шигельозі / М.Д. Чемич, М.А. Андрейчин, В.В. Захлебаєва // Інсрекційні хвороби. - 2009. - № 2. - C. 42-47.

9. Koletzko S. Acute infectious diarrhea in children / S. Koletzko, S. Osterrieder // Dtsch. Arztebl. Int. - 2009. - Bd. 106, N 33. S. 539-547.

10. Focus on acute diarrhoeal disease / [F. Baldi, M.A. Bianco, G. Nardone et al.] // World J. Gastroenterol. - 2009. - Vol. 15, N 27. - P. 3341-3348.

11. Gastric acid reduction leads to a alteration in lowel intestinal microflora / [T. Kanno, T. Matsuki, M. Oka et al.] // Biochem. Biophyskes. Commun. - 2009. - Vol. 381, N 4. - P. 666-670.

\section{PECULIARITIES OF ACUTE INTESTINAL INFECTIONS CAUSED BY OPPORTUNISTIC MICROORGANISMS AND VIRUSES IN MODERN CONDITIONS}

\author{
O.M. Chemych, K.S. Polovian, N.I. Ilyina, N.H. Malysh
}

SUMMARY. It is proved that in the etiological structure of acute intestinal infections Klebsiella pneumoniae (31,4\%), viruses (15,7\%), EPKP (11,4\%), Pseudomonas aeruginosae $(10,0 \%)(p<0,01)$ predominate in the modern context. Performed exploration of integrated intoxication markers of the first level (body temperature, nausea, vomiting, weakness, headache, abdominal pain any location, etc.) allowed to state that in acuity endogenous intoxication increases in all patients $(p<0,05-0,001)$. Integrative indicators of endogenous intoxication significantly elevated in all patients point at pronounced intoxication syndrome in the acute period. There is an increase of leukocyte index of intoxication (4,3-5,5 times), hematological toxicity index (5,0-7,4), the index of leukocytes shift (2,1-2,6). Instead lymphocytic index decreases significantly (2,0-2,2 times). While investigating the microbiocenosis of intestinal canal in the acute period is was found the decrease of the bifid bacterium, lactobacilli and Escherichia coli number with increasing levels of other UPM representatives, hemolytic E. coli and genus Candida fungi $(p<0,05-$ 0,001 ).

Key words: acute intestinal infection, clinical findings, epidemiology, integrative indicators of endogenous intoxication, microbiocenosis of intestinal canal.

Отримано 16.12.2014 р. 